\title{
Arven efter Wilson
}

I 100-året for den amerikanske præsident Woodrow Wilsons proklamation af begrebet 'den nationale selvbestemmelsesret' gøres et forsøg på at følge dette begreb fra at være værktøj til at nyskabe Europa efter Første Verdenskrig til at blive legitimation for koloniernes frigørelse fra deres europæiske magtherrer.

FN-pagten indledes smukt med at tale om "vi, De Forenede Nationers folk..." og signalerer dermed, at ikke alene staterne, men disses befolkninger nu bekendtgør de høje fundamentale mål, som ligger til grund for den nye fredsorganisation FN. Dette præambel til selve pagten kan tillige ses som et tegn på, at de folk, som udgør staterne, på en måde også er aktører i den moderne folkeret.

Det blev interessant illustreret ved en dom fra EU-domstolen i Luxembourg i februar 2018, hvor udstrækningen af en fiskeriaftale mellem EU og Marokko blev nærmere defineret. Det betyder, at farvandet ud for Vestsahara, som Marokko okkuperede, da det spanske koloniherredømme ophørte i 1975, ikke er omfattet af fiskeriaftalen. Det blev tydeligt af domstolen begrundet med, at medtagelsen af Vestsahara ville krænke folkeretlige regler om selvbestemmelsesretten.

Mere generelt har det dog givet problemer, at udtrykket 'folk' mildest talt ikke er entydigt, og at der strengt taget ikke lå nogen dyb mening i udtrykket, som det blev brugt ved FN's oprettelse. Folkeforbundet - FN's forgænger-organisation, om man så må sige - havde ikke i sit grundlæggende dokument, Folkeforbundspagten, en lignende bestemmelse. Og dog var det omkring denne organisations grundlæggelse, at begrebet 'den nationale selvbestemmelsesret' for første gang blev manifest formuleret.

Den amerikanske præsident Woodrow Wilson udviklede begrebet - som led i sine mange gode ideer om fredsskabelse i det Europa, som gennem Første Verdenskrig havde lidt så ubeskriveligt. Wilson var med en hærskare af jurister, geografer, politikere og militærfolk kommet til Europa i 1918 for på Versailles-konferencen at bistå

Henrik Døcker er journalist og forfatter og har i 60 år skrevet om international politik og ret i dansk dags- og tidskriftpresse. 
Europas ledende magter med at lægge nye grænser - og tilgodese en række folkegruppers nationale interesser.

Uden at indgå direkte i Wilsons sidenhen berømte ' 14 punkter' var selvbestemmelsesretten et bærende princip for hans store visioner om en åben, fri verden, præget af liberalistiske ideer. Var selvbestemmelsesretten blevet påberåbt allerede under den fransk revolution og under en række opstande i 1848, forud for at en stribe europæiske stater fik frie forfatninger, og havde endog Vladimir Lenin peget på den som argument for at få styrtet zaren, så blev det Wilson, som gav begrebet international pondus.

USA, der selv havde løsrevet sig fra det dengang mægtige Storbritannien, opkastede sig således til en tidlig forkæmper for respekt for befolkningers ret til at skulle have lige så meget at sige som statsmagten.

Mest træffende er det måske at betragte Wilsons mange ideer som frø for en langstrakt udvikling, der små 50 år senere i det store og hele kom til at afskaffe verdens kolonier. I 1920'erne gjaldt det imidlertid først og fremmest at give en række europæiske folkeslag egne stater, samtidig med at folkegrupper uden for Europa fik status som mandater under Folkeforbundet, en slags umyndige, som forlenedes med en særlig beskyttet status i 13 oversøiske områder, der i det væsentlige havde hørt under Det Osmanniske Rige eller Tyskland.

Men som frugt af Versailles-konferencen og i dyb overensstemmelse med nationalitetsprincippet kom Tjekkoslovakiet, Finland, Estland, Letland, Litauen og Serbo-Kroatien/Jugoslavien til verden, mens Polen blev genoprettet, og Ungarn blev skilt ud fra Østrig.

\section{Øst- og Centraleuropas kludetæppe}

De mange nye grænser, der blev trukket på europakortet, skabte imidlertid ingenlunde 'rene' stater. Fremdeles var der, særligt i Central- og Østeuropa, tale om et 'kludetæppe' af nationaliteter. Mange mennesker i denne del af Europa følte snarere deres identitet knyttet til deres religion eller deres hjemegn. Det nyoprettede Folkeforbund, Wilsons ambitiøse projekt, indgik derfor mindretalsaftaler med såvel Polen som Tjekkoslovakiet, Serbo-Kroatien, Rumænien og Grækenland, hvortil kom lignende bestemmelser i fredstraktaterne med Østrig, Bulgarien, Ungarn og Tyrkiet.

Når i alt fire kejserriger - det russiske, det tyske, det østrig-ungarske og det osmanniske - styrtede i grus i forbindelse med verdenskrigen, hang det bl.a. sammen med, at titularbefolkningen (altså den folkegruppe, landet var opkaldt efter) ikke udgjorde et flertal i to af dem.

Problemerne kan illustreres ved, at en tredjedel af befolkningen i Polen 
udgjordes af nationale mindretal, og at Ungarn blev reduceret til en tredjedel af sin oprindelige størrelse, således at en tredjedel af befolkningen kom til at leve uden for den nye ungarske stats grænser. En egentlig politisk autonomi gjaldt dog kun Danzig, Memel og Øvre Schlesien (i dag henholdsvis Gdansk, Klaipeda og Slask), de øvrige områder fik alene særrettigheder vedrørende religion, sprog og kultur. Nyt i folkeretten var, at individer kunne indklage deres egen stat for et internationalt tribunal med udsigt til at opnå kompensation for krænkelse af mindretalsaftalerne.

Det bør imidlertid understreges, at der ingenlunde var tale om et generelt beskyttelsessystem for folkegrupper i Europa. Flere lande, heriblandt Danmark, havde ingen forpligtelser over for Folkeforbundet. Vi havde imidlertid fået nyreguleret den dansk-tyske grænse på basis af en folkeafstemning, som førte til Nordslesvigs tilbagevenden til Danmark.

\section{Ikke retfærdighedsskabende}

Alt i alt viste det sig, at selvbestemmelsesretten ikke var let at anvende som et retfærdighedsskabende redskab ud fra diverse folkegruppers interesser, men snarere kom til at være et argument, som kunne bruges, når det var hensigtsmæssigt for stormagterne. Østrigerne ville eksempelvis gerne tilsluttes Tyskland, men en slagen fjende skal ikke belønnes med nyt territorium, indbyggerne på Ålandsøerne var ved en folkeafstemning gået ind for tilslutning til Sverige, men det nye selvstændige Finland, hvorfra øer- ne havde været administreret, kunne ikke svækkes ved landafståelse. Til gengæld fik Ålandsøerne en demilitariseringsgaranti, som bl.a. har fritaget ålændingene for at forrette finsk militærtjeneste.

De rettigheder, der her på forskellig vis var tale om, gjaldt altså kun Europa, hvad man dengang betragtede som 'den civiliserede verden'. Og der var ikke stor konsekvens i det hele. Tilsagn om egen stat til fx kurderne og armenierne blev der eksempelvis ikke givet - med blodige konsekvenser senere hen.

Rødderne til selvbestemmelsesretten kan findes i ideer om folkesuverænitet, altså at forestillingen om statens højhedsret over et område kun er legitim, når den udgår fra befolkningen, som på demokratisk vis har haft ret til at ytre sig om styreformen. Efter denne forestilling er et autokratisk eller diktatorisk regime uforeneligt med selvbestemmelsesretten.

Ved en nærmere analyse af disse begreber er det nyttigt at skelne mellem 'folk' og 'nation', hvorefter førstnævinte er betegnelse for en folkegruppe, der har fælles etnisk oprindelse, sprog og kultur, og sidstnævnte er den gruppe mennesker, der statsligt, politisk og administrativt udgør en stats befolkning, er dens statsborgere. Fx giver det ingen mening at tale om det congolesiske folk, når den tidligere belgiske koloni havde 69 forskellige stammer (folkegrupper), mens det giver mening at tale om den congolesiske nation, der tager sit udgangspunkt i den belgiske kolonisering fra slutningen af 1800-tallet. 


\section{USA som promotor}

Hvorom alting er, så forplantede de wilsonske ideer, affødt af oprydningen efter Første Verdenskrigs omkalfatring af Europas grænser, sig kun langsomt til den øvrige verden. Endnu en verdenskrig skulle til, før end den nationale selvbestemmelsesret som sådan skulle blive løftestang for et større antal ufrie folks ret til at danne egne stater.

Forløberne hertil kan atter findes i et amerikanske udspil, nu til Atlanterhavserklæringen af 1941, hvori USA's præsident Franklin Roosevelt og Storbritanniens premierminister Winston Churchill bl.a. relancerede ideen om folkenes selvbestemmelsesret. Det hele var pakket ind i gode ideer til en fredeligere verden oven på Anden Verdenskrig, men amerikanernes pres på gamle europæiske kolonimagter - foruden Storbritannien bl.a. Frankrig, Belgien og Holland - var klart. Så meget mere som mange soldater fra disses oversøiske besiddelser havde sat livet til på europæiske slagmarker.

Den nye fredsorganisation, som skulle afløse Folkeforbundet, var ikke mindst disse to statsmænds værk. I de Forenede Nationers pagt blev retten til national selvbestemmelse da også direkte indskrevet (i art. 1 og art 55) om end i en kursorisk form, hvoraf intet bestemt kan udelades.

Vi skal frem til 1960 for at finde en mere konkret, håndfast udmelding fra FN, nemlig FN-generalforsamlingens resolution om uafhængighed til kolonilandene og -folkene. Men denne folkeretligt ikke-bindende erklæring var tvetydig, idet det bl.a. hed, at "ethvert forsøg på delvis eller total opløsning af den nationale enhed og integritet er uforenelig med FN-pagtens formål og principper”. Eftersom de folkeretslærde ikke havde opnået enighed om definitionerne på 'folk' eller 'stat', bestod der fortsat uklarhed om, hvornår en folkegruppe havde ret til løsrivelse ud fra nogle tilsyneladende objektive kriterier. To oprørske provinser, Katanga (i dag Shaba) i Congo og Biafra i Nigeria, fik eksempelvis ikke det internationale samfunds støtte til løsrivelse.

Under alle omstændigheder fremgik det af en erklæring fra den daværende Afrikanske Enhedsorganisation (OAU) i 1964, at medlemsstaterne respekterede de grænser, der var gældende ved områdernes selvstændighed. Hermed blev en almindelig løsrivelsesret formelt afvist, hvilket dog ikke langt senere udelukkede, at Eritrea løsrev sig fra Etiopien i 1993, og at Sydsudan udskiltes af Sudan som selvstændig stat i 2011.

I 1966 vedtoges to $\mathrm{FN}$-menneskeretskonventioner om henholdsvis politiske og borgerlige rettigheder på den ene side og sociale, økonomiske og kulturelle rettigheder på den anden og begge med en enslydende art. 1, der sikrer realiseringen af den nationale selvbestemmelsesret. Den reelle politiske effekt af selvbestemmelsesretten i disse to konventioner er vanskelig at lodde. Den store frigørelsesbølge for de mange kolonier - omkring 80 alt i alt - var allerede sat i skred.

Det skal indskydes, at der i medfør af FN-pagten blev oprettet et særligt Formynderskabsråd for ikke-selv- 


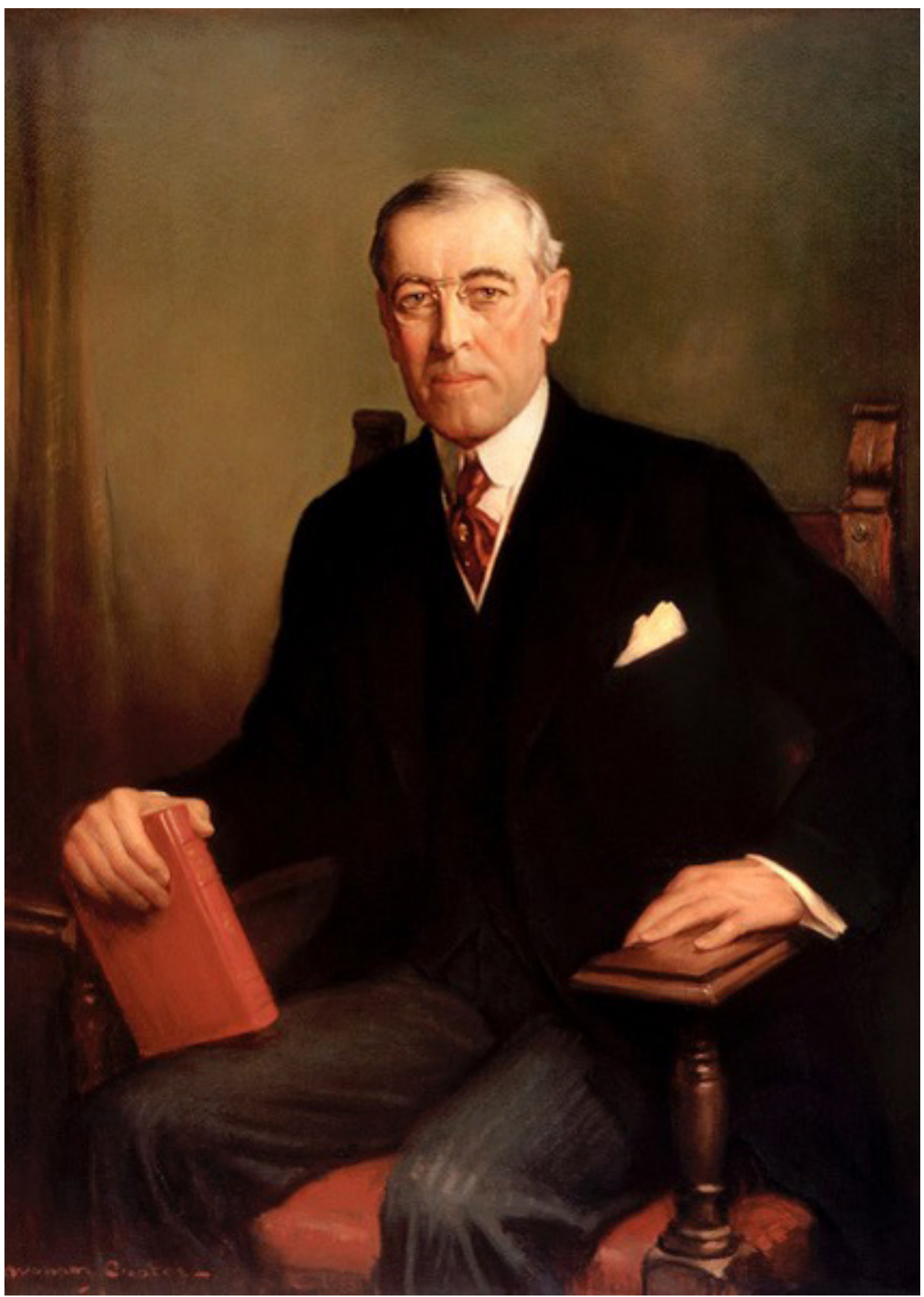

FOTO: www.whitehouseresearch.org/assetbank-whha/action/viewHom via Wikimedia Commons

Officielt portræt af præsident Woodrow Wilson, olie på canvas 
stændige områder, dengang ti hidtidige folkeforbundsmandater plus Italiensk Somaliland. De skulle bistås til med tiden at opnå selvstyre eller selvstændighed, hvilket de gradvist opnåede, således at rådet kunne nedlægges, da det sidste område, Stillehavsøen Palau, blev selvstændig i 1994.

Rigtig mange debatter i FN's Generalforsamling styrkede kolonifolkenes stærke ønsker om selvstændighed, som satte i gang, da Britisk Indien opdeltes i de to nye stater Indien og Pakistan - en opdeling nødvendiggjort af modsætninger mellem de mange hinduistiske indere og muslimerne.

\section{Frie under fredelige former}

FN's sikkerhedsråd fik en særlig rolle, da det ved en resolution i 1948 oprettede den jødiske stat Israel på det britiske mandatområde Palæstina. Hermed fik alverdens jøder et længe eftertragtet land - noget som mandatmagten Storbritannien havde forudskikket ved den såkaldte Balfour-erklæring af 1919, der dog tvetydigt talte om etablering af 'et jødisk nationalt hjem' i Palæstina. At de derboende arabiske borgere - hvoraf nogle i $\varnothing$ vrigt var kristne - siden hen valgte at kalde sig palæstinensere bidrog på en måde til at skabe forvirring $\mathrm{i}$ begreberne.

Afrikas sidste egentlig koloniområde, Vestsahara - oprindeligt en spansk besiddelse - har dog ikke opnået selvstændighed på grund af uenighed om hvor stor en befolkningsgruppe, der har ret til at deltage i en folkeafstemning om territoriets fremtidige status.
Siden 1976 har det som verdens sidste større koloniområde været besat af Marokko. Der er tale om en 'frossen' konflikt, idet talrige forhandlinger ikke har fået én af parterne til at sænke kården. Enkelte andre små ikke-selvstændige områder så som Gibraltar og Ny Kaledonien har valgt fortsat at sortere under henholdsvis Storbritannien og Frankrig.

Et stort antal kolonier havde en fredelig overgang til selvstændighed, Det gjaldt således to franske i Nordafrika, Marokko og Tunesien, og de britiske kolonier Ghana, Sierra Leone og Nigeria. Blodig blev frihedskampen i Algeriet, Laos og Cambodja, Indonesien og Malaya (siden hen Malaysia), Sydafrika, Mocambique og Angola. Selv den mest fremskridtsvenlige kolonimagt, som måtte ønske at tage FN's højtidelige besværgelser til afskaffelse af kolonialismen alvorligt, stod over for særlige problemer, når der ikke var en enkelt uafhængighedsbevægelse at overdrage magten til. Markant var de problemer, som Congo oplevede, da Belgien slap tøjlerne dér i 1960, og der straks opstod magtkampe inden for den snævre sorte elite, som skulle indtage regeringsmagten.

En totalopgørelse af omstændighederne for alle afrikanske, asiatiske og latinamerikanske områders kolonifrigørelse skal ikke forsøges her. Men det kan fastslås, at langt de fleste koloniers overgang til uafhængighed forløb fredeligt, og at det er lykkedes Storbritannien at bevare tætte bånd til sine tidligere besiddelser inden for Commonwealth, også kaldet Det Britiske Statssamfund. 
Var selvbestemmelsesretten, som udviklet i FN, i det væsentlige tiltænkt de fremmede folkeslag, som skulle afkaste koloni-åget, så er maksimen også blevet brugt på andre måder. Som fx da Argentina ved en landgang på den lille gletsjer- $\varnothing$ Syd Georgien i Sydatlanten i 1982 udløste en - om end kortvarig - krig med Storbritannien. Det var til forsvar for de udelukkende britiske indbyggerne i den ligeledes sydatlantiske øgruppe Falklandsøerne, at den britiske flåde blev sendt af sted. Efter to en halv måned var den argentinske styrke nedkæmpet - falklænderne blev dermed sikret mod at blive indbyggere i det daværende argentinske militærdiktatur.

\section{Østtimor og Kosovo}

Tydelige nationale frihedskampe i nyere tid skulle føre til uafhængighed for henholdsvis Østtimor og Kosovo - men for begges tilfælde ad blodige omveje

De skal kort beskrives her, fordi de begge gennemlevede en overgangsfase, hvor FN så at sige var statholder. $\emptyset$ sttimor blev efter 200 år som regulær portugisisk koloni 'givet fri', da Portugals kolonirige ved nellikerevolutionen i 1974 brød sammen. Selvstændigheden varede blot ni dage, da den mægtige ostindiske nabo Indonesien besatte Østtimor - i forvejen besad det den vestlige del af øen. En betydelig modstand fra den lokale modstandsbevægelse FRETIL-
IN banede vej for en frigørelse, som muliggjordes ved det indonesiske Suharto-regimes fald i 1998. Ved en folkeafstemning gik et stort flertal af timoreserne i 1999 ind for selvstændighed, som blev endelig i 2002 efter en FN-overvåget overgangsperiode. Alt dette kunne dog ikke forebygge alvorlige og blodige træfninger efterfølgende mellem forskellige politiske grupper. En FN-politistyrke har medvirket til at dæmpe gemytterne og få opbygget et nationalt politi.

Kosovo var oprindelig en provins af Serbien, der som sådan havde status af delstat i Jugoslavien indtil dens opløsning i begyndelsen af 1990'erne.

En tiltagende forskelsbehandling stigende til undertrykkelse fra serbisk side over for det albansk-talende flertal (90 pct. af provinsens befolkning) udløste med tiden direkte væbnede konfrontationer. Frygt for et regulært folkedrab på kosovo-albanerne udløste i 1999 en række NATO-staters bombardementer af serbiske mål, hvorefter der blev opnået en våbenhvile.

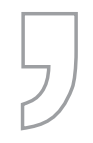

Den nationale selvbestemmelsesret har uanset
mange proklamationer, resolutioner og konventioner
slået igennem på meget forskellig vis rundt om i
verden. At ophøje den til en regulær menneskeret
som i de nævnte to FN-konventioner af 1966 har
ikke flyttet stort.
Det militære indgreb, som efter manges opfattelse havde karakter af en humanitær intervention, havde dog ikke opbakning fra FN's Sikkerhedsråd. Indtil selvstændigheden i 2008 styredes Kosovo som et pro-

BAGGRUND 
tektorat under FN og beskyttet af en NATO-fredsstyrke på 50.000 mand. Lejlighedsvise sammenstød mellem kosovo-albanere og kosovo-serbere blev taget i opløbet ved de fremmede, deriblandt danske, soldaters mellemkomst. En albansk guerilla, forkortet UCK, blev afvæbnet i 1999. I modsætning til Østtimor er Kosovo ikke medlem af FN, idet et russisk-kinesisk veto i FN's sikkerhedsråd må forventes herimod.

Den nationale selvbestemmelsesret har uanset mange proklamationer, resolutioner og konventioner slået igennem på meget forskellig vis rundt om i verden. At ophøje den til en regulær menneskeret som i de nævnte to FN-konventioner af 1966 har ikke flyttet stort, så meget mere som de fleste FN-konventioner ikke har noget sanktionssystem - man kan eventuelt klage til en kontrolkomité, som ikke har nogle reelle implementeringsmekanismer.

\section{Mindretal}

Om selvbestemmelsen skal realiseres ved internt selvstyre inden for en stat eller ved regulær selvstoendighed vil som regel blive afgjort af moderstatens styrke. Selvstyrets omfang eller intensitet, om man vil, afhænger ofte af historiske forhold. Når Danmark eksempelvis har oprettet delstatsparlamenter for Grønland og Færøerne, er disse områder på en måde bedre stillet end et mindretal. Et sådant har vi da kun ét af, nemlig det tyske i Sønderjylland.

Nationale mindretal er genstand for særlig opmærksomhed fra Europarå- dets rammekonvention herom, som gennem sine rapporter påpeger kritisable forhold for mindretallene.

Denne europæiske aftale har dog sine svagheder, eftersom Europaråds-staterne egenmægtigt fastslår, om de overhovedet har et mindretal - $\mathrm{fx}$ erkender Frankrig og Tyrkiet ikke eksistensen af mindretal hos sig - uanset sådanne folkegrupper som bretonerne, korsikanerne og kurderne.

Set i et længere tidsperspektiv blev det i Europa efter Anden Verdenskrig Sydtyrol, som kom til at volde nogle af de længst varende mindretalsproblemer. Det oprindeligt østrigske område var efter Første Verdenskrig blevet afstået til Italien. Herefter blev 15 tysktalende kommuner sluttet sammen med Trentino, idet den almindelige italienske betegnelse blev Alto Adige (Øvre Adige). Den italieniseringspolitik, som igangsattes af Benito Mussolinis fascistiske Italien, fortsatte til 1960 'erne, uanset at 93 pct. af Sydtyrols befolkning var tysktalende og blot 3 pct. italiensktalende - i dag taler 69 pct. tysk og 26 pct. italiensk.

Den italienske stat gav støtte til $\mathrm{fx}$ syditalienere, som ville flytte til Sydtyrol i håb om at forskyde befolkningssammensætningen, men flere tysktalende områder satte sig til væbnet modværge. Attentater og eksplosioner skabte usikkerhed, alt mens østrigske og italienske regeringsrepræsentanter forhandlede, og også FN var inddraget. I 1972 opnåede området en autonom status i den italienske stat, men først i 1992 blev aftalerne tilfredsstillende for de tysktalende ved tilkæmpelse af den såkaldte finansautonomi, 
som betød, at provinsen fik rådighed over 90 pct. af sine indtægter. Den er så i øvrigt i dag én af Italiens mest velstående provinser.

Principper og normer for staters opførsel væltes hyppigt omkuld af rene og skære magtforhold. Folkeafstemninger har undertiden givet udfald, som har bragt områder fra asken $\mathrm{i}$ ilden, $\mathrm{i}$ andre tilfælde har valgproceduren gjort vold på demokratiske principper som fx det ukrainske Krims indlemmelse i Rusland. Løsrivelse fra et moderland som $\mathrm{fx}$ Kosovo fra Serbien blev erklæret folkeretsmæssigt af Den Internationale Domstol i Haag, mens den canadiske provins Quebecs forsøg på at løsrive sig fra Canada af dette lands Højesteret fandtes at krænke landets forfatning - akkurat som i øvrigt Cataloniens forsøg på at løsrive sig fra Spanien. Den canadiske højesteret tilføjede i øvrigt som sin opfattelse, at løsrivelse kun kunne accepteres under exceptionelle omstændigheder, som $\mathrm{fx}$ når et områdes befolkning havde fået sine rettigheder groft krænket.

Selv om FN i princippet støtter alverdens folkeslags opnåelse af selvstændighed, er det værd at mærke sig, at spredte folkegrupper verden over befinder sig godt selv med et moderland $\mathrm{i}$ en anden verdensdel. Spørg fx indbyggerne i Gibraltar, Ny-Kaledonien eller Guadeloupe.

Vilkår og betingelser er forskellige. Men rigtig mange mindretal lever under usle vilkår i fremmede lande. Det nyeste forfærdende tilfælde udgøres af de muslimske rohingyaer i Myanmar, som aldrig dér opnåede mindretalsrettigheder for slet ikke at tale om statsborgerskab trods ophold i generationer. Det samme gælder palæstinenserne i en række arabiske nabolande til Israel. De har den tvivlsomme status af statsløse og uønskede. De hjælpes ikke af internationale konventioner. 